million which is divided in the ratio of about $5 / 7$ between central and local government funds. At the time the council was set up the Department of Education and Science undertook to meet the costs of staffing and accommodating it (a sum which is expected to amount to $£ 450,000$ in $1968-69$ ), and also committed an annual sum for research work rising to $£ 100,000$ a year by 1968-69. Because this was insufficient to meet the council's needs, local education authorities agreed to take a major financial stake in the council's work. In 1967-68 this amounted to $£ 385,000$, and estimates for 1968-69 and for each of the two following years have been provisionally set at about $£ 700,000$.

The council's largest single project, costing a total

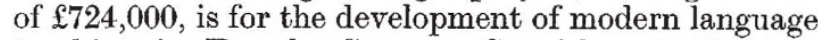
teaching in French, German, Spanish and Russian. This project, which was started last year, is being carried out by a team at the University of York and should be completed by 1974. Another costly project which was also started last year is the curriculum development project in technology for secondary schools. At the University of Leeds a project for teaching English to children of non-English-speaking immigrants is in progress. As part of the sixth form programme, $£ 14,000$ is being spent at the University of Birmingham, and the same amount at the Universities of Oxford and Cambridge on research into the relationship between university requirements and sixth form curricula.

Because two examinations - the GCE and CSE exams-are held consecutively in the summer term, there is a serious loss of teaching time, and the council hopes that it will eventually be possible to conduct the two examinations simultaneously. Probably the most controversial subject in the council's examination work is the procedure used to "effect the comparability of standards between the fourteen CSE boards" and to establish the equivalence of ordinary level GCE and grade 1 CSE examinations. Members of the council hope that inter-board cooperation on this subject will be developed on a much larger and more systematic scale in the next few ycars, and a pilot scheme for establishing a bank of questions for comparability procedures is in progress.

But there is little doubt that the most important part of the council's activities remains the reform of the sixth form curriculum in England and Wales. It is, of course, no secret that the proposals the council has already put forward were widely criticized. It proposed that sixth formers should take two instead of three subjects at A-level, and that these should be backed up by "elective courses" which would be examined, and general courses which would not. The report says little about the disagrecment which this proposal provoked-it does, however, admit that these proposals are "being urgently and seriously discussed", and that "there will clearly be great difficulty in finding a widely acceptable pattern". But the report is confident that agreement exists on aims, and that it is only on means that there are differences. The next step, it suggests, may be to consider in depth the relationship between sixth form and undergraduate work in particular subjects and at particular universities. Universities which do not agree with the council's proposals are urged to put up ideas of their own. It cannot, however, be said that the report gives any idea of the urgency of the problem, or any hope of a quick settlement.

\section{Coastal Concern}

THE amount of money spent by the British Government under the National Parks and Access to the Countryside Act, 1949, amounts to no more than the cost of one cigarette every three years per head of population. This statistic emerged at a conference on the coast of East Anglia organized by the National Parks Commission last year. The report, just published (HMSO, $£ 15 s$ ), is another in a series on the state of coastal development and preservation (Nature, 218, 913 ; 1968); the first time there has been any coordinated attempt to plan the coastlines of Britain.

The regional planning officers felt that the area formed a fairly coherent whole for the purposes of planning and agreed that the overall objective should be to concentrate on developing the northern coasts so as to shield southern East Anglia from further development. At present Suffolk has the largest reserve of unspoilt coastline near to London-35 miles from Kessingland south to the River Deben-and the problem is whether the area should be more intensively developed for public use. Essex County Council felt that its coast was already over-developed and is starting a continuous coastal green belt scheme and exploring possible inland recreational schemes as counterattractions to the coast. The population of Essex is expected to rise by half a million between 1961 and 1981 and Ipswich is planned to double in size during the same period. So the plans are coming none too soon. Norfolk, on the other hand, still has a coastline which is 80 per cent undeveloped and its planning officers intend to keep it that way. They will be greatly helped by the National Parks Commission, which has designated some two-thirds of the coast an area of outstanding natural beauty. For the remaining third the council is planning a number of compact seaside resorts developed behind the coast as an alternative to the present piecemeal, scattered settlements. One such holiday township for 10,000 will be based on Sea Palling where the present population is only 2,500 ; two other similar settlements, one for 10,000 and one for 20,000, are planned for the east Norfolk coast.

As in the other coastal studies, the planning officers agreed that the costs of development should be spread more evenly to include those urban areas whose ratepayers use the coastal facilities, thereby easing the burden from the rather underpopulated coastal areas themselves. This was agreed to be more equitable than simply increasing the proportion of exchequer grants, now about 75 per cent of the total sum. Investment in better roads in East Anglia is equally important. The conference was critical of the Ministry of Transport, and many delegates complained that most of the money was spent on freight-carrying roads, while recreational traffic was largely neglected. Perhaps this was why much of the area was relatively unspoilt, but Essex stressed that holidays are not luxuries and generate traffic which also deserves consideration on social and economic grounds. The discussion, however, remains academic as long as money is not available. While this practical limitation will probably hold for some time, it is good to see both the Government and the local authorities aware of the problems. 